\title{
Passive Transfer of the Resistance to Tumor with RNA
}

\author{
Matsuro Fukushima, Seiro Machida, Akira Hokama, \\ Masari KoJika, TeiJi Nishikawa, Akira Kikuchi and \\ YosHINOBU ISHIKAWA \\ The First Department of Surgery, Hirosaki University School \\ of Medicine, Hirosaki
}

\begin{abstract}
Fugushima, M., Machida, S., Hokama, A., Kojtka, M., Nishikawa, T., KrkvoHi, A. and IsHikawa, Y. Passive Transfer of the Resistance to Tumor with $\dot{R} N A$. Tohoku J. exp. Med., 1974, $112(2), 155-163-$ RNA was extracted from the spleen cells of the rats or rabbits which had been immunized with Yoshida sarcoma (YS-immune rats or rabbits). Twenty per cent of the recipient rats previously injected with the RNA survived against the inoculation of YS tumor cells. Allogeneic lymphoid cells were incubated with the RNA from the YS-immune rats and then transferred to the recipient rats. Eight days after the transfer, YS tumor cells were inoculated into the peritoneal cavities of the same animals. The survival rate of these recipient rats was $50 \%$. In similar experiments, when the RNA from the YS-immune rabbits was used in the incubation, instead of the rat RNA, the survival rate of the recipient rats was $30 \%$. Splenic RNA from the normal rats and rabbits and from the rabbits sensitized with splenic supernate of normal rats exhibited no antitumor effect. The antitumor effect of RNA derived from the YS-immune rats was lost by treatment with RNAse. - passive transfer; tumor specific resistance; RNA
\end{abstract}

The recipient rat exhibits a resistance to the growth of Yoshida sarcoma (YS) tumor after receiving the allogeneic lymphoid cells of the donor rats which had acquired a resistance to YS (Ishikawa et al. 1968). The anti-tumor activity of the supernate $(5000 \times \mathrm{g})$ from allogeneic spleen cells immunologically sensitized with YS or methylcholanthrene-induced tumors has been proved previously (Fukushima et al. 1969; Ishikawa et al. 1971). The mechanism of these phenomena and the properties of the effective substance in the sensitized lymphoid cells are unknown.

Regarding transplantation immunity, an immunological response of lymphoid cells can be transformed by incubation with the RNA-rich preparation extracted from lymphoid tissues or macrophages which had previously been exposed to a specific transplantation antigen (Fishman 1961; Mannick and Egdahl 1962; Cohen and Parks 1964; Friedman 1964).

Several authors reported that RNA extracted from the lymphoid tissues which had previously been exposed to specific tumor antigens may give a specific immunoreactivity to allogeneic normal animals (Alexander et al. 1967; Kennedy et al.

Received for publication, October 16, 1973. 
1969; Pilch and Ramming 1970; Ramming and Pilch 1970). These reports also revealed that the lymphoid cells can be transformed to a specific immunoreactive status, when they are incubated with RNA extracted from the lymphoid tissues previously exposed to a specific tumor antigen of chemically induced tumor.

In this study, we have revealed that rats acquire a passively transferred tumorspecific resistance to YS by means of administration of the RNA from YS-immune rats and rabbits, and also by means of transfe: of the allogeneic lymphoid cells which have been incubated with the RNA of YS-immune animals.

\section{Materials and Methods}

\section{Animals and tumor}

Donryu uniform strain male rats, weighing 120 to $140 \mathrm{~g}$, and adult rabbits weighing 3.5 to $4 \mathrm{~kg}$ were used. Tumor cells used were YS maintained in adult rats through serial intraperitoneal transplantations at 6 -day intərvals.

\section{Immunization}

The method of immunizing rats and rabbits against the YS cells was described in detail previously (Fukushima et al. 1969). Briefly, the rats, which had received an intraperitoneal inoculation of $10^{5} \mathrm{YS}$ cells, were treated with $2 \mathrm{mg} / \mathrm{kg}$ of Mitomycin C. The surviving rats received again with $10^{5}$ tumor cells. The third and fourth challenges of $10^{6}$ tumor cells to these rats were done at an interval of 3 weeks. The rabbits had an intramuscular injection of $5000 \times \mathrm{g}$ supernate obtained from the homogenized $10^{8}$ YS tumor cells followed by the second intraperitoneal and the third intravenous injection of the supernate at an interval of one week each. As a control, some rabbits were immunized with the supernate $(5000 \times \mathrm{g})$ from normal rat's spleen cells by the same method.

\section{Extraction of $R N A$}

Fifteen YS-immune rats, 30 normal rats, 3 YS-immune rabbits, 3 normal rabbits, and 3 rabbits immunized with normal rat's spleen supernate $(5000 \times \mathrm{g})$ were employed. Splenectomy was performed aseptically under ether anesthesia. The spleens were stored in dry ice until all spleens of each group were extirpated. RNA was extracted from these spleens of each group by the method of Ralph and Bellamy (1964). The spleens were homogenized for 5 min at top speed in twofold volume of a mixture composed of equal parts of $0.5 \%$ aqueous sodium naphthalene disulphonate solution and $90 \%$ aqueous phenol (previously distilled) containing $0.1 \%$ 8-hydroxyquinoline using a Waring blender cooled in an ice bath. The homogenate was stirred gently for $30 \mathrm{~min}$ at $20^{\circ} \mathrm{C}$ by a stirrer, and then centrifuged at $5000 \times \mathrm{g}$ for $5 \mathrm{~min}$. The opalescent aqueous supernate was carefully removed taking care to avoid contamination with debris from the interphase. The supernate was shaken again with its half volume of phenol solution containing $0.1 \% 8$ hydroxyquinoline for $5 \mathrm{~min}$. The upper aqueous layer was again carefully removed, then added with two volumes of chilled $95 \%$ ethanol. The precipitates formed were collected by centrifugation at $750 \times \mathrm{g}$. This preparation was washed with $70 \%$ ethanol, $95 \%$ ethanol (twice), acetone (twice), and ether, then dried in an evaporating desiccator. This crude RNA was dissolved in an appropriate amount of $0.01 \mathrm{M}$ sodium acetate buffer $(\mathrm{pH}$ 5.1). Equal volumes of $2.5 \mathrm{M}$ potassium phosphate buffer (pH 8) and 2-methoxyethanol were added. The mixture was shaken vigorously for $5 \mathrm{~min}$. The clear supernatant layer was carefully withdrawn avoiding the interphase materials, and mixed with an equal volume of $0.2 \mathrm{M}$ sodium acetate and a half volume of $1 \%$ cetyltrimethylammonium bromide (CTA). The suspension containing the CTA-RNA precipitate was chilled at $0^{\circ} \mathrm{C}$ for $5 \mathrm{~min}$ and centrifuged at $5000 \times \mathrm{g}$. The purified CTA-RNA was washed three times with chilled $70 \%$ ethanol containing $0.1 \mathrm{M}$ sodium acetate to reconvert CTA-RNA back to Na-RNA and to remove CTA-acetate. RNA was recovered by centrifugation and the pellet was washed 
with $95 \%$ ethanol (twice), acetone (twice), and ether, then dried in an evaporating desiccator. The properties of the RNA preparation were routinely examined both with ultraviolet absorption spectroscopy and with Schlieren optics by analytical cantrifuge (Hitachi CA I type).

Preparation of spleen and lymph node cell suspensions

The excised spleens or mesenterial, axillary and inguinal lymph nodes from normal rats were trimmed free of fat and fibrous tissues, minced with fine scissors in cold balanced salt solution containing $100 \mu \mathrm{g} / \mathrm{ml}$ streptomycin and $100 \mathrm{U} / \mathrm{ml}$ penicillin, then passed through two layers of nylon gauze and centrifuged twice at $800 \mathrm{rpm}$ for $7 \mathrm{~min}$.

\section{Incubation of lymphoid cells with $R N A$}

The lymphoid cells were suspended in RNA solution $(0.5 \mathrm{ml} / \mathrm{ml})$ at a concentration of $10^{8}$ cells $/ \mathrm{ml}$, then incubated at $37^{\circ} \mathrm{C}$ for $30 \mathrm{~min}$ in a water bath with shaking. Viability of these cells determined by Eosin-exclusion was 88 to $95 \%$. An aliquot of RNA solution $(0.5 \mathrm{mg} / \mathrm{ml}$ ) was treated with $50 \mu \mathrm{g} / \mathrm{ml}$ of RNAse or DNAse (Washington Biochemical Co. Ltd., Freehold, Newzealand) for $30 \mathrm{~min}$ at $37^{\circ} \mathrm{C}$.

\section{Experimental groups}

The following four types of experiment were performed: 1) The recipient rats were inoculated with $10^{5} \mathrm{YS}$ tumor cells intraperitoneally 8 days after the injection of $0.5 \mathrm{mg}$ of the RNA derived from spleens of each group. 2) The recipient rats received an intraperitoneal inoculation of $10^{5} \mathrm{YS}$ tumor cells 8 days after intraperitoneal transfer of $10^{8}$ allogeneic lymphoid cells which had been incubated with RNA $(0.5 \mathrm{mg})$ of each group. 3) The recipient rats were inoculated with $10^{5}$ YS tumor cells intraperitoneally 8 days after the injection of the RNA which had been pretreated with RNAse or DNAse. 4) The recipient rats were inoculated with $10^{5}$ YS tumor cells intraperitoneally 8 days after the transfer of the $10^{8}$ lymphoid cells which had been incubated with the RNA pretreated with RNAse or DNAse.

\section{Results}

\section{Property of $R N A$ extracted from spleen cells}

Purified RNA was white, powdery, and soluble in water and balanced salt solution. The weight of RNA to the weight of donor's spleen was $2.4 \mathrm{mg} / \mathrm{g}$ in YS-immune rats, $2.2 \mathrm{mg} / \mathrm{g}$ in normal rats, $2.7 \mathrm{mg} / \mathrm{g}$ in YS-immune rabbits, $2.1 \mathrm{mg} /$ $\mathrm{g}$ in normal rabbits, and $1.8 \mathrm{mg} / \mathrm{g}$ in rabbits which had been immunized with splenic supernate $(5000 \times \mathrm{g})$ of normal rat. Fig. 1 shows the absorption spectrum of each RNA solution $(0.05 \mathrm{mg} / \mathrm{ml})$. The ratios of absorbancies at $230 \mathrm{~nm}$ and $280 \mathrm{~nm}$ to $260 \mathrm{~nm}$ were 0.45 and 0.48 , respectively, for the RNA extracted from the spleens of YS-immune as well as normal rats. A $230 \mathrm{~nm} / \mathrm{A} 260 \mathrm{~nm}$ was 0.42 and A 280 $\mathrm{nm} / \mathrm{A} 260 \mathrm{~nm}$ was 0.49 for the RNA extracted from the YS-immune rabbit spleens. A $230 \mathrm{~nm} / \mathrm{A} 260 \mathrm{~nm}$ was 0.49 and A $280 \mathrm{~nm} / \mathrm{A} 260 \mathrm{~nm}$ was 0.5 for the RNA extracted from normal rabbit's spleens. For the RNA derived from the rabbits which had been immunized with the splenic supernate of normal rats, A $230 \mathrm{~nm} / \mathrm{A} 260$ $\mathrm{nm}$ was 0.49 and A $280 \mathrm{~nm} / \mathrm{A} 260 \mathrm{~nm}$ was 0.48 . The ratio of A $280 \mathrm{~nm} / \mathrm{A} 260$ $\mathrm{nm}$ of the RNA extracted from spleen cells of various donors was smaller than 0.5 , and this result compared satisfactory with that mentioned by Bell and Dray (1969).

Sedimentation patterns obtained by analytical ultracentrifugation of RNA 


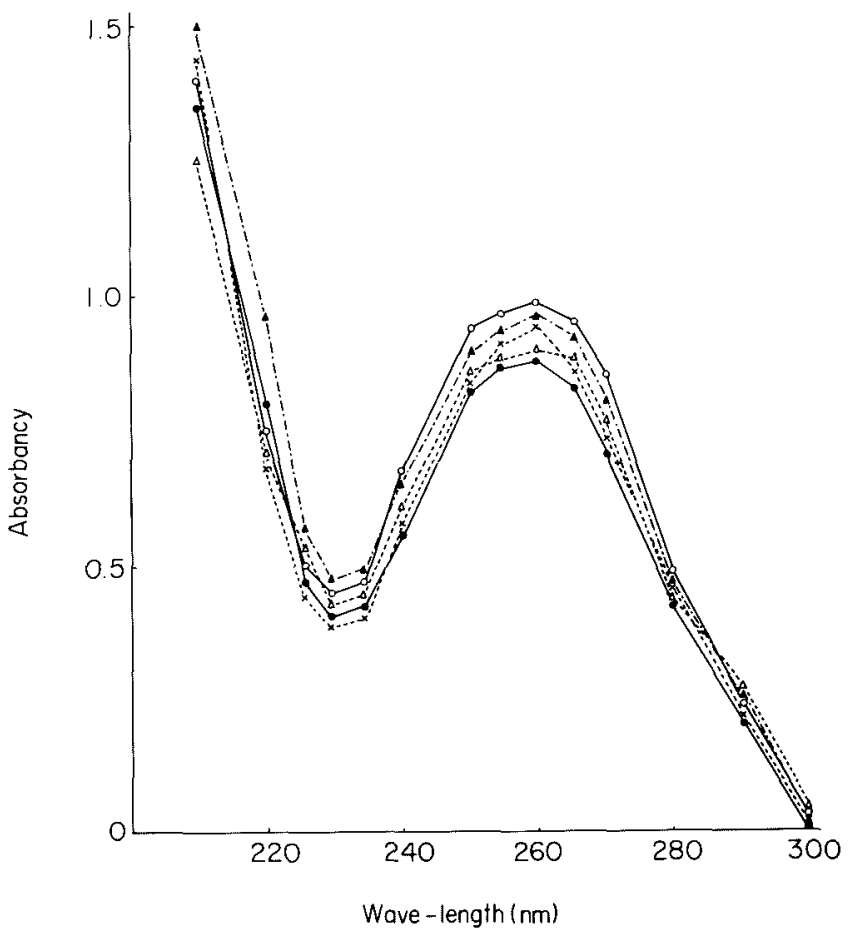

Fig. 1. Absorption spectra of RNA solutions $(0.005 \%)$. The spectra show a concavity at $230 \mathrm{~nm}$ and a convexity at $260 \mathrm{~nm}$. The absorbancies of these RNA are 0.39 to 0.47 at $230 \mathrm{~nm}$ and 0.88 to 0.99 at $260 \mathrm{~nm}$. The ratios of absorbancies at $230 \mathrm{~nm}$ and $280 \mathrm{~nm}$ to $260 \mathrm{~nm}$ are all within 0.5 . —— normal rat's spleen RNA; $\longrightarrow$ YS. immune rat's spleen RNA; $A$-...-A normal rabbit's spleen RNA; $\times$....-. YS-immune rabbit's spleen RNA; .-_-_ rat's splenic supernate-immune rabbit's spleen RNA.

solutions (2\%) from rat and rabbit spleens are shown in Fig. 2. There were two components (approx. $17 \mathrm{~S}$ and $25 \mathrm{~S}$ ) on rat's and rabbit's RNA. There was no difference in sedimentation pattern between immunized and normal spleens or between animal species. Biuret reaction was negative for each RNA.

Survival of the rats which received the allogeneic $R N A$ or the allogeneic lymphoid cells incubated with the same RNA

The results of the two experiments are summarized in Table 1. Twenty per cent of the rats survived against the intraperitoneal challenge of YS tumor cells $\left(10^{5}\right)$ when they had previously been injected with splenic RNA from the YSimmune rats (YS-immune rat RNA). All rats previously injected with normal allogeneic RNA died from tumor growth within 20 days after intraperitoneal inoculation of $10^{5}$ YS tumor cells. Fifty per cent of the rats injected in advance with the allogeneic lymphoid cells $\left(10^{8}\right)$ which had been incubated with the YSimmune rat RNA survived against the YS tumor inoculation $\left(10^{5}\right)$. The rats 


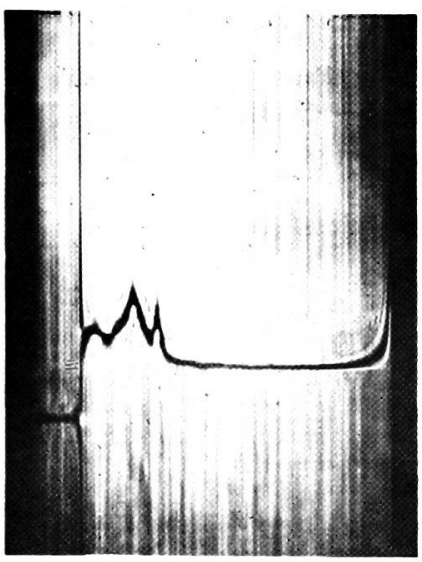

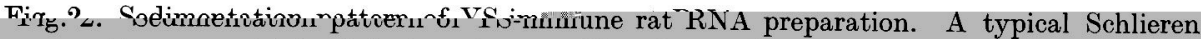
pattern was obtained during ultracentrifugation study of $2 \%$ YS-immune rat RNA in $0.1 \mathrm{M}$ acetate buffer ( $\mathrm{pH} 5.1$ ) plus $0.025 \mathrm{M} \mathrm{NaCl}$. Sedimentation was carried out in the roter (RA 60 type) of the analytical ultracentrifuge (Hitachi CA I type). This photograph was taken $25 \mathrm{~min}$ after attaining speed $(51200 \mathrm{rpm})$ at $18.9^{\circ} \mathrm{C}$. It reveals a high molecular weight component $(25 \mathrm{~S})$ and a low molecular weight component (17 S).

TABLE 1. Numbers of survived rats after tumor transplantation. The rats received in advance the allogeneic $R N A$ or the allogeneic lymphoid cells incubated with the allogeneic $R N A$

\begin{tabular}{|c|c|c|c|c|c|c|c|c|c|c|c|c|c|c|c|c|c|c|}
\hline $\begin{array}{l}\text { Administered RNA } \\
\text { and lymphoid cells }\end{array}$ & $\begin{array}{l}\mathrm{D} \\
0\end{array}$ & $\begin{array}{r}\text { ay } \\
2\end{array}$ & $\begin{array}{c}\text { aft } \\
4\end{array}$ & 6 & $\begin{array}{c}\text { tum } \\
8\end{array}$ & & $\begin{array}{l}\operatorname{tr} 2 \\
12\end{array}$ & 14 & $\begin{array}{l}\text { plan } \\
16\end{array}$ & 18 & $\begin{array}{l}\text { tion } \\
202\end{array}$ & & 24 & & & & & $\begin{array}{l}\text { Survival } \\
\text { rate }(\%)\end{array}$ \\
\hline $\begin{array}{l}\text { YS-immune rat's } \\
\text { spleen RNA* (im) } \dagger\end{array}$ & 10 & " & $"$ & $"$ & $"$ & $"$ & $"$ & $"$ & 8 & 6 & 5 & 3 & " & 2 & $n "$ & " " " & 2 & 20 \\
\hline $\begin{array}{l}\text { YS-immune rat's } \\
\text { spleen RNA (ip) })_{+}^{+}\end{array}$ & 5 & " & $"$ & $"$ & " & " & " & 4 & " & 2 & 1 & " & " & " & 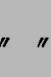 & " " " & 1 & 20 \\
\hline $\begin{array}{l}\text { Normal rat's } \\
\text { spleen RNA (ip) }\end{array}$ & 10 & " & $"$ & $"$ & $"$ & 8 & 5 & 3 & 1 & " & 0 & & & & & & & 0 \\
\hline $\begin{array}{l}\text { Spleen cells§ } \\
\text { incubated with } \\
\text { YS-immune rat's } \\
\text { spleen RNA (ip) }\end{array}$ & 10 & $"$ & $" \prime$ & $"$ & " & " & $"$ & " & 9 & 8 & " & $"$ & 7 & 6 & $5 "$ & $" \quad "$ & 5 & 50 \\
\hline $\begin{array}{l}\text { Lymph node cells§ } \\
\text { incubated with } \\
\text { YS-immune rat's } \\
\text { spleen RNA (ip) }\end{array}$ & 8 & $"$ & $n$ & " & " & " & " & 5 & 4 & " & " & $"$ & " & " & $"$ " & $" 1$ & 4 & 50 \\
\hline $\begin{array}{l}\text { Spleen cells§ } \\
\text { incubated with } \\
\text { normal rat's } \\
\text { spleen RNA (ip) }\end{array}$ & 7 & " & $" \prime$ & 6 & " & " & 5 & " & 4 & 2 & $"$ & 1 & 0 & & & & & 0 \\
\hline Control & 10 & " & " & $"$ & 8 & $"$ & 7 & 4 & 2 & 0 & & & & & & & & 0 \\
\hline
\end{tabular}

* Dose of RNA was $0.5 \mathrm{mg}$ per rat.

$\dagger$ Intra-muscular injection.

† Intraperitoneal injection.

$\S$ Number of the transferred lymphoid cells: $10^{8}$ cells per rat. 
TABLE 2. Numbers of survived rats after tumor transplantation. The rats received in advance the xenogeneic RNA or the allogeneic lymphoid cells incubated with the xenogeneic $R N A$

\begin{tabular}{|c|c|c|c|c|c|c|c|c|c|c|c|c|c|c|c|c|c|c|c|}
\hline $\begin{array}{l}\text { Administered RNA } \\
\text { and lymphoid cells }\end{array}$ & $\begin{array}{l}\mathrm{D} \\
0\end{array}$ & ay & aft & $\begin{aligned} \mathrm{er} \\
6\end{aligned}$ & & $\begin{array}{l}\text { nor } \\
10\end{array}$ & $\begin{array}{l}\operatorname{tr} s \\
12\end{array}$ & 14 & $\begin{array}{l}\text { la } \\
16\end{array}$ & $\begin{array}{l}\text { ata } \\
18\end{array}$ & 20 & & 24 & 26 & 28 & 30 & & & $\begin{array}{l}\text { Survival } \\
\text { rate }(\%)\end{array}$ \\
\hline $\begin{array}{l}\text { YS-immune rabbit's } \\
\text { spleen RNA* (ip) }\end{array}$ & 10 & " & $"$ & $"$ & $"$ & " & 8 & "I & 6 & $"$ & $"$ & 5 & 3 & 2 & $"$ & $"$ & $"$ & 2 & 20 \\
\hline $\begin{array}{l}\text { Normal rabbit's } \\
\text { spleen RNA (ip) }\end{array}$ & 8 & " & $"$ & 7 & " & $"$ & $" \prime$ & 6 & " & 4 & 2 & $n$ & 0 & & & & & & 0 \\
\hline $\begin{array}{l}\text { Rat's splenic super- } \\
\text { nate-immune rabbit's } \\
\text { spleen RNA (ip) }\end{array}$ & 7 & $"$ & $"$ & "I & $"$ & " & 5 & 4 & " & 2 & 1 & 0 & & & & & & & 0 \\
\hline $\begin{array}{l}\text { Spleen cells } \dagger \\
\text { incubated with YS- } \\
\text { immune rabbit's } \\
\text { spleen RNA (ip) }\end{array}$ & 10 & $n$ & $"$ & " & $"$ & 8 & $"$ & $"$ & 6 & " & 5 & $"$ & $"$ & 4 & $"$ & 3 & $"$ & 3 & 33 \\
\hline $\begin{array}{l}\text { Lymph node cells } \dagger \\
\text { incubated with YS- } \\
\text { immune rabbit's } \\
\text { spleen RNA (ip) }\end{array}$ & 7 & $"$ & $"$ & $" \prime$ & 6 & 5 & $"$ & $"$ & $"$ & 4 & $"$ & 3 & 2 & $"$ & $"$ & $"$ & $n$ & 2 & 29 \\
\hline $\begin{array}{l}\text { Spleen cells incubated } \\
\text { with normal rabbit's } \\
\text { spleen RNA (ip) }\end{array}$ & 8 & "I & $"$ & $"$ & 7 & $" 1$ & $"$ & 6 & 4 & 2 & $"$ & $" \prime$ & 0 & & & & & & \\
\hline $\begin{array}{l}\text { Lymph node cells in- } \\
\text { cubated with rat's } \\
\text { splenic supernate- } \\
\text { immune rabbit's RNA } \\
\text { (ip) }\end{array}$ & 8 & " & $"$ & " & 7 & " & $"$ & $"$ & 5 & 4 & 3 & $"$ & 1 & 0 & & & & & 0 \\
\hline Control & 7 & $" 7$ & $"$ & " & " & 6 & 5 & " & 3 & 2 & 1 & 0 & & & & & & & \\
\hline
\end{tabular}

* Dose of RNA was $0.5 \mathrm{mg}$ per rat.

$\uparrow$ Number of the lymphoid cells: $10^{8}$ cells per rat.

injected in advance with the allogeneic spleen cells incubated with splenic RNA of normal rats could not survive against the YS tumor inoculation. In the control group, all rats died within 16 days after YS tumor inoculation.

Survival of the rats which received the xenogeneic $R N A$ or the allogeneic lymphoid cells incubated with the xenogeneic $R N A$

Twenty per cent of the rats previously injected with splenic RNA of the YSimmune rabbits (YS-immune rabbit RNA) survived against the tumor inoculation. The rats injected with splenic RNA of normal rabbits and the rats which had received splenic RNA of the rabbits sensitized with splenic supernate from normal rats all died within. 24 days after YS tumor inoculation. Three of 10 rats which received the allogeneic spleen cells incubated with YS-immune rabbit RNA, and 2 of 7 rats which received the allogeneic lymph node cells incubated with YSimmune rabbit RNA survived against YS tumor inoculation. When the transferred allogeneic lymphoid cells were incubated with normal rabbit RNA or RNA from the rabbits immunized with splenic supernate of normal rats, all reci- 
TABLE 3. Numbers of survived rats after tumor transplantation. The rats received in advance the YS-immune rat's splenic RNA treated with RNAse or DNAse, or the allogeneic lymphoid cells incubated with the same treated $R N A$

\begin{tabular}{|c|c|c|c|c|c|c|c|c|c|c|c|c|c|c|c|c|c|c|c|}
\hline $\begin{array}{l}\text { Administered RNA } \\
\text { and lymphoid cells }\end{array}$ & $\begin{array}{l}\mathrm{D} \\
0\end{array}$ & $\begin{array}{l}\text { ay } \\
2\end{array}$ & $\begin{array}{c}\text { aft } \\
4\end{array}$ & $\begin{array}{r}\text { er } \\
6\end{array}$ & 8 & $\begin{array}{l}\text { aor } \\
10\end{array}$ & $\begin{array}{l}\operatorname{tr} \\
12\end{array}$ & $\begin{array}{l}\operatorname{ans} \\
14\end{array}$ & $\begin{array}{l}\text { pla } \\
16\end{array}$ & $\begin{array}{l}\text { nta } \\
18\end{array}$ & $\begin{array}{l}\text { tion } \\
20\end{array}$ & & 24 & & 28 & 30 & & & $\begin{array}{l}\text { Survival } \\
\text { rate }(\%)\end{array}$ \\
\hline $\begin{array}{l}\text { YS-immune rat's } \\
\text { spleen RNA treated } \\
\text { with RNAse (ip) }\end{array}$ & 5 & $"$ & $"$ & $"$ & 3 & $"$ & $"$ & $"$ & 2 & $"$ & $"$ & $"$ & 1 & " & $"$ & 0 & & & $n$ \\
\hline $\begin{array}{l}\text { YS-immune rat's } \\
\text { spleen RNA treated } \\
\text { with DNAse (ip) }\end{array}$ & 6 & " & " & $"$ & $"$ & 5 & 4 & $" \prime$ & " & 3 & $"$ & 2 & $n$ & $"$ & " & $"$ & " & 2 & 33 \\
\hline $\begin{array}{l}\text { Spleen cells incubated } \\
\text { with YS-immune rat's } \\
\text { spleen RNA treated } \\
\text { with RNAse }\end{array}$ & 7 & $"$ & $"$ & $n$ & 6 & 5 & $"$ & 4 & 3 & $"$ & 2 & 1 & 0 & & & & & & 0 \\
\hline $\begin{array}{l}\text { Spleen cells incubated } \\
\text { with YS-immune rat's } \\
\text { spleen RNA treated } \\
\text { with DNAse }\end{array}$ & 7 & " & " & $" \prime$ & 5 & 4 & $"$ & $"$ & $"$ & 3 & $"$ & $"$ & $"$ & $"$ & $"$ & $"$ & $"$ & 3 & 43 \\
\hline $\begin{array}{l}\text { Lymph node cells in- } \\
\text { cubated with YS- } \\
\text { immune rat's spleen } \\
\text { RNA treated with } \\
\text { DNAse }\end{array}$ & 7 & $"$ & $"$ & $" \prime$ & 6 & 4 & " & $"$ & 3 & $"$ & 2 & $"$ & $"$ & " & $"$ & $"$ & $"$ & 2 & 29 \\
\hline Control & 7 & $"$ & $"$ & $"$ & 4 & $"$ & " & $"$ & 3 & $"$ " & 2 & 0 & & & & & & & 0 \\
\hline
\end{tabular}

pient rats died from tumor growth within 26 days after YS tumor inoculation. All control rats died within 22 days after YS tumor inoculation (Table 2).

Influence of RNAse and DNAse upon the YS-immune rat RNA

When the recipient rats received the YS-immune rat RNA which had been pretreated with RNAse, they could not survive against tumor inoculation. The survival rate of the recipient rats which had received the YS-immune rat RNA pretreated with DNAse was $33 \%$. When the transferred allogeneic lymphoid cells had been incubated with the YS-immune rat RNA pretreated with DNAse some of the recipient rats survived against YS tumor inoculation. When the transferred allogeneic spleen cells had been incubated with the YS-immune rat RNA pretreated with RNAse all recipient rats died within 28 days after inoculation of YS tumor cells (Table 3).

\section{Discussion and Conclusion}

We have shown previously that passive immunity is feasible with the administration of the subcellular fraction obtained from tumor-resistant animals (Fukushima et al. 1969; Ishikawa et al. 1971). There is little proof regarding the property of the effective substance and mechanism of passive immunity with the administration of the subcellular fraction obtained from tumor-sensitized lymphoid cells. In order to clarify these problems, we attempted an experiment with RNA 
extracted from tumor-sensitized allogeneic and xenogeneic lymphoid cells.

Twenty per cent of the recipient rats injected with YS-immune rat RNA survived against the intraperitoneal inoculation of YS tumor cells. The recipient rats which received the allogeneic lymphoid cells incubated with YS-immune rat RNA showed a 50\% survival against YS tumor inoculation. Twenty per cent of the recipient rats which were injected with xenogeneic YS-immune rabbit RNA, and $30 \%$ of the recipient rats which received the allogeneic lymphoid cells incubated with YS-immune rabbit RNA survived against YS tumor inoculation. When the YS-immune rat RNA was treated with RNAse, its anti-tumor effect disappeared completely. On the other hand, DNAse exerted little influence on the anti-tumor effect of YS-immune rat RNA.

No rats survived against the YS tumor inoculation after they had been injected with RNA derived from normal rats, normal rabbits, or from rabbits sensitized with splenic supernate of normal rats. When the transferred allogeneic lymphoid cells had been incubated with normal splenic RNA or with the RNA derived from the rabbits previously sensitized with the splenic supernate of normal rats, the recipient rats could not survive against YS tumor inoculation.

Alexander et al. (1967) have reported that anti-tumor effect is recognized in nucleic acid extracted from the xenogeneic lymphocytes sensitized with methylcholanthrene-induced sarcomas. However, cross immunity for this nucleic acid has not been proved. Kennedy (1969) and Ramming and Pilch (1970) have reported that normal lymphoid cells may exhibit anti-tumor effect in vitro as well as in vivo, after being incubated with RNA obtained from chemical-induced mouse tumor. In our experiments, the immune response from xenogeneic RNA was almost equal to that from allogeneic RNA, and no serious side effect on the recipients was recognized.

Recently, it has been reported (Rigby 1971) that exogenous RNA is useful for augmenting the effect of immunotherapy. The successful utilization of xenogeneic immune RNA to mediate an anti-tumor immune response may suggest its use as a model for immunotherapy in human cancer.

\section{References}

1) Alexander, P., Delorme, E.J., Hamilton, L.D.G. \& Hall, J.G. (1967) Effect of nueleic acids from immune lymphocytes on rat sarcoma. Nature, 213, 569-572.

2) Bell, C. \& Dray, S. (1969) Conversion of non-immune spleen cells by ribonucleic acid of lymphoid cells from an immunized rabbit to produce $M$ antibody of foreign light chain allotype. J. Immunol., 103, 1196-1211.

3) Cohen, E.P. \& Parks, J.J. (1964) Antibody production by nonimmune spleen cells incubated with RNA from immunized mice. Science, 144, 1012-1013.

4) Fishman, M. (1961) Antibody formation in vitro. J. exp. Med., 114, 837-856.

5) Friedman, H. (1964) Antibody plaque formation by normal mouse spleen cell cultures exposed in vitro to RNA from immune mice. Science, 146, 934-936.

6) Fukushima, M., Sato, T., Kasai, T., Komaba, M., Yagihashi, H. \& Ishikawa, Y. (1969) Immunological response of splenic subcellular fraction obtained from induced Yoshida sarcoma-resistant animals. Tohoku J. exp. Med., 99, 247-254.

7) Ishikawa, Y., Fukushima, M., Sato, T., Komaba, M. \& Kakuta, H. (1968) Im- 
munological response of adoptive transfer for the growth of Yoshida sarcoma. Gann, 59, 453-460.

8) Ishikawa, Y., Fukushima, M., Sato, T., Komaba, M., Yagihashi, H., Hokama, A. \& Kojika, M. (1971) Passive transfer of tumor-specific resistance to methylcholanthreneinduced sarcomas in rats. Tohoku J. exp. Med., 103, 195-201.

9) Kennedy, C.T.C., Cater, D.B. \& Hartreit, F. (1969) Protection of $\mathrm{C}_{3} \mathrm{H}$ mice against BP 8 tumor by RNA extracted from lymph nodes and spleens of specifically sensitized mice. Acta pathol. microbiol. scand., 77, 196-200.

10) Mannick, J.A. \& Egdahl, R.H. (1962) Transplantation of nonimmune lymph node cells to state of transplantation immunity by RNA. Ann. Surg., 156, 356-366.

11) Pilch, Y.H. \& Ramming, K.P. (1970) Transfer of tumor immunity with ribonucleic acid. Cancer, 26, 630-637.

12) Ralph, R.K. \& Bellamy, A.R. (1964) Isolation and purification of undegraded ribonucleic acids. Biochem. biophys. Acta, 87, 9-16.

13) Ramming, K.P.\& Pilch, Y.H. (1970) Transfer of tumor-specific immunity with RNA: Demonstration by immune cytolysis of tumor cells in vitro. J. nat. Cancer Inst., 45, 543-553.

14) Rigby, P.G. (1971) The effect of "exogenous" RNA on the improvement of syngeneic tumor immunity. Cancer Res, 31, 4-6. 